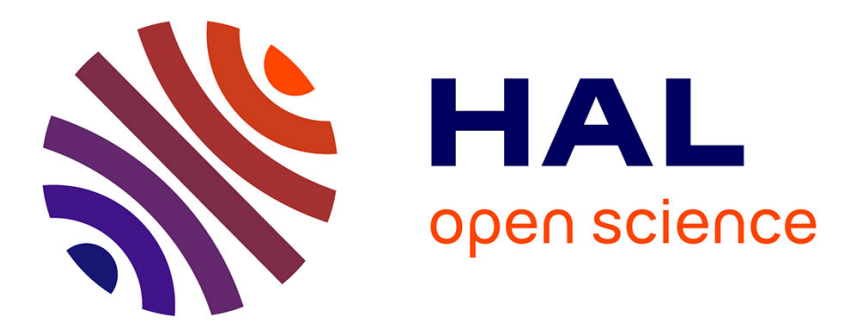

\title{
Effect of culturing lactic acid bacteria with varying skim milk concentration on bacteria survival during heat treatment
}

Xiangshu Suo, Song Huang, Juan Wang, Nan Fu, Romain Jeantet, Xiao Dong Chen

\section{To cite this version:}

Xiangshu Suo, Song Huang, Juan Wang, Nan Fu, Romain Jeantet, et al.. Effect of culturing lactic acid bacteria with varying skim milk concentration on bacteria survival during heat treatment. Journal of Food Engineering, 2021, 294, pp.110396. 10.1016/j.jfoodeng.2020.110396 . hal-03099223

\section{HAL Id: hal-03099223 \\ https://hal.inrae.fr/hal-03099223}

Submitted on 6 Jan 2021

HAL is a multi-disciplinary open access archive for the deposit and dissemination of scientific research documents, whether they are published or not. The documents may come from teaching and research institutions in France or abroad, or from public or private research centers.
L'archive ouverte pluridisciplinaire HAL, est destinée au dépôt et à la diffusion de documents scientifiques de niveau recherche, publiés ou non, émanant des établissements d'enseignement et de recherche français ou étrangers, des laboratoires publics ou privés.

\section{(1) (1) $\$$}

Distributed under a Creative Commons Attribution - NonCommercial - NoDerivatives| 4.0 


\title{
Effect of culturing lactic acid bacteria with varying skim milk concentration on bacteria survival during heat treatment
}

\author{
Xiangshu Suo $^{a}$, Song Huang ${ }^{c}$, Juan Wang ${ }^{\mathrm{d}}$, Nan Fu ${ }^{\mathrm{a}, *}$, Romain Jeantet ${ }^{\mathrm{b}}$, Xiao Dong Chen ${ }^{\mathrm{a}, * *}$ \\ ${ }^{a}$ China-Australia Joint Research Center of Future Dairy Manufacturing, School of Chemical and Environmental Engineering, College of Chemistry, Chemical Engineering \\ and Materials Science, Soochow University, Suzhou, 215123, Jiangsu Province, China \\ ${ }^{\mathrm{b}}$ STLO, Agrocampus Ouest, INRA, 35000, Rennes, France \\ ${ }^{\mathrm{c}}$ Xbiome, Shenzhen, 518000, China \\ ${ }^{\mathrm{d}}$ Xiao Dong Pro-health (Suzhou) Instrumentation Co Ltd, Xiangcheng Zone, Suzhou, 215143, Jiangsu Province, China
}

\section{A R T I C L E I N F O}

\section{Keywords:}

High solids milk

Lactobacillus casei Zhang

Preadaptation

Probiotics

Stress response

Thermotolerance

\begin{abstract}
A B S T R A C T
Four lactic acid bacteria (LAB) strains were cultured in reconstituted skim milk with different solids contents to compare the thermotolerance of resulting cultures. As milk concentration was increased from 5 to 30 wt $\%$, the population of non-lactose-fermenting strains increased by around $1 \log$ at stationary growth phase. High solids milk maintained relative stable $\mathrm{pH}(\Delta \mathrm{pH}<0.5)$ when fermented with a lactose-fermenting strain, compared to a drastic $\mathrm{pH}$ drop by 1.35 in low solids milk. All four strains cultured in 20 or $30 \mathrm{wt} \%$ milk demonstrated significant improvements in cell survival (remaining viability $>10^{8} \mathrm{CFU} / \mathrm{mL}$ ) and growth capability after heat treatment at $65^{\circ} \mathrm{C}$ for $10 \mathrm{~min}$, indicating a general thermoprotective effect irrespective of metabolic pathways. Besides cellular response to high osmolality during bacterial growth, we proposed that the increased concentration of protective dairy components and the increased viscosity and thermal resistance of culture medium also contributed to the excellent thermotolerance.
\end{abstract}

\section{Introduction}

A number of lactic acid bacteria (LAB) strains demonstrate probiotic effects under in vitro and in vivo conditions (FAO/WHO, 2001). For instance, Lactobacillus casei Zhang exerts antioxidant effects on hyperlipidemic rats, and it can influence the intestinal microbiota of humans (Kwok et al., 2014; Zhang et al., 2010). Lactobacillus rhamnosus GG exhibits antimicrobial activity against certain intestinal pathogens (De Keersmaecker et al., 2006; Hudault et al., 1997). Lactobacillus plantarum P8 can alleviate anxiety in stressed adults (Lew et al., 2018). Lactobacillus casei BL23 has immunomodulatory properties and can attenuate colitis (Bauerl et al., 2010; Watterlot et al., 2010). These strains have attracted great attention both as pharmaceuticals and as functional foods. The beneficial effect to host after administrating the microorganisms takes place when the number of viable microorganisms in a probiotic product goes beyond a required value. The minimum count of bacteria should be $>10^{7} \mathrm{CFU}$ per gram or milliliter of product at the time of consumption as recommended by the International Dairy Federation, while the present trend generally requires a total dose $>10^{9}$ CFU per serving of food (Balthazar et al., 2017; Corona-Hernandez et al., 2013; Fenster et al., 2019). Therefore, it is crucial to establish large-scale production for probiotic products that contain adequate levels of viable cells with well retained functionalities. In such products, the stress tolerance of bacteria is a key factor determining their ability to adapt to the challenging environment during processing, storage, and then digestion in human bodies (Hussain et al., 2013; Zhao et al., 2019). Among the different stresses that exert on LAB cells during food processing, the ability of cells to tolerate thermal stress is often a key criterion, which could be attributed to two considerations. First, heating is often encountered in food processing, such as in spray drying where liquid culture is converted to powder form for extending its shelf-life (Fu and Chen, 2011; Schutyser et al., 2012). Second, LAB cells with enhanced thermotolerance often exhibit cross-adaptation effect towards other stresses such as oxidative stress and bile salts (Desmond et al.,

\footnotetext{
* Corresponding author. China-Australia Joint Research Center of Future Dairy Manufacturing, School of Chemical and Environmental Engineering, College of Chemistry, Chemical Engineering and Materials Science, Soochow University, 199 Ren-Ai Rd., Suzhou Industrial Park, 215123, Suzhou, Jiangsu, China.

** Corresponding author. China-Australia Joint Research Center of Future Dairy Manufacturing, School of Chemical and Environmental Engineering, College of Chemistry, Chemical Engineering and Materials Science, Soochow University, 199 Ren-Ai Rd., Suzhou Industrial Park, 215123, Suzhou, Jiangsu, China.

E-mail addresses: nan.fu@suda.edu.cn (N. Fu), xdchen@mail.suda.edu.cn (X.D. Chen).
} 
2001; Dijkstra et al., 2014).

The intrinsic stress tolerance of LAB is significantly affected by culture conditions used, including the composition of culture medium, temperature, $\mathrm{pH}$, and oxygenation conditions (Dijkstra et al., 2014; Gaucher et al., 2020). A variety of modifications on culture medium have been attempted in the literature to improve the robustness of LAB towards environmental stresses. In earlier studies, components that were unfermentable by $\mathrm{LAB}$, such as $\mathrm{NaCl}$ and sucrose, were added to culture medium to induce the adaptation of cells towards osmotic stress, but the improvement of cell survival after dehydration was relatively insignificant (Ferreira et al., 2005; Kets et al., 1996; Linders et al., 1997; Silva et al., 2004). A recent study showed that supplementing $\mathrm{Ca}^{2+}$ to the growth medium of LAB can increase the thermotolerance of cells as well as their survival after spray drying (Wang et al., 2020). Similar effects have been reported for Propionibacterium freudenreichii by adding lactose and $\mathrm{NaCl}$ during the cultivation of cells (Gaucher et al., 2020). Huang et al. (2016a) utilized concentrated sweet whey as a 2-in-1 medium for both growth and spray drying of Lactobacillus casei BL23 and Propionibacterium freudenreichii ITG P20, and the results showed that bacterial population after growth and residual viability in spray-dried powder were both increased with the increase of the total solids of sweet whey from $5 \mathrm{wt} \%$ to 20 or $30 \mathrm{wt} \%$. Cells cultured in the highly concentrated medium demonstrated substantially improved stability against heat, acid, and bile salts stresses, which was ascribed to the over-expression of key stress proteins and the accumulation of compatible solutes (Huang et al., 2016b). Given that sweet whey is a byproduct from the production process of rennet-type cheese, its availability as fermentation substrate could be limited. An alternative substrate, which is low in cost and versatile in use, will be a great advantage for the large-scale production of probiotic products.

Reconstituted skim milk (RSM) is one of the most reputed protective agents for LAB cells (Fu and Chen, 2011). Previous studies showed that a number of skim milk components, such as whey protein, calcium, and lactose, are capable of protecting the activity of probiotic cells under adverse conditions during spray drying, storage, and digestion (Huang and Chen, 2013; Mattila-Sandholm et al., 2002; Rajam et al., 2012; Su et al., 2019; Wang et al., 2016). While $10 \mathrm{wt} \%$ RSM is a common fermentation substrate to grow $\mathrm{LAB}$ and to examine their fermentative activity, increasing the concentration of RSM could be a viable approach to yield LAB cells with enhanced stress tolerance as observed for sweet whey.

The objective of this work was to investigate the thermotolerance of LAB cells when cultured in RSM with different solids contents as growth medium. Four probiotic lactobacilli strains, namely Lactobacillus casei Zhang (LCZ), Lactobacillus rhamnosus GG (LGG), Lactobacillus plantarum P8 (LP) and Lactobacillus casei BL23 (LCBL23), were grown in RSM ranged between 5.0 and $35.0 \mathrm{wt} \%$, using the standard growth medium (5.0 wt \% MRS broth) as control. The rheological behavior and LAB growth were first studied for each type of milk, and then the thermotolerance of cells was evaluated using heat treatment at 65 and $70{ }^{\circ} \mathrm{C}$. The possible mechanisms underlying the enhanced thermotolerance of LAB grown in high solids RSM were discussed.

\section{Material and methods}

\subsection{Microorganisms}

Lactobacillus casei Zhang (LCZ) and Lactobacillus plantarum P8 (LP) were generously provided by the Key Laboratory of Dairy Biotechnology and Engineering, Inner Mongolia Agricultural University, China. Lactobacillus rhamnosus GG (LGG) was obtained from a commercial product (Culturelle ${ }^{\circledR}$, New Haven, CT, USA). Lactobacillus casei BL23 was kindly provided by UMR1219 MICALIS (INRA-AgroParisTech, Jouy-En-Josas, France). All cultures were maintained on MRS agar plates and stored at $4{ }^{\circ} \mathrm{C}$, with subculture to fresh medium every 7 days. The inoculum of each strain was prepared by transferring a single colony on the agar plate to $10 \mathrm{~mL}$ of MRS broth, which was then incubated at $37^{\circ} \mathrm{C}$ for $12 \mathrm{~h}$.

\subsection{Materials and medium preparation}

MRS powder was purchased from Oxoid (Hampshire, UK). Agar powder and peptone were purchased from Solarbio (Beijing, China). Skim milk powder was purchased locally (Devondale ${ }^{\circledR}$, Australia). The composition of milk powder was $35 \mathrm{~g}$ protein, $1 \mathrm{~g}$ fat, $53 \mathrm{~g}$ carbohydrate, $0.45 \mathrm{~g}$ sodium and $1.15 \mathrm{~g}$ calcium per $100 \mathrm{~g}$ solids, according to the product specification. All medium and solution were prepared with Milli-Q water (Milli-Q ${ }^{\circledR}$ Direct 16, Merck Millipore, Darmstadt, Germany).

MRS agar plates were prepared by adding agar powder to reconstituted MRS broth at a concentration of $11.0 \mathrm{~g} / \mathrm{L}$. All MRS broth, MRS agar and glassware were sterilized at $121^{\circ} \mathrm{C}$ for $15 \mathrm{~min}$. The RSM media were prepared by dissolving skim milk powder in Milli-Q water to achieve the total solids contents of 5.0, 10.0, 20.0, 25.0, 30.0, 35.0 and $40.0 \mathrm{wt} \%$, respectively. The resulting milk samples were autoclaved at $105{ }^{\circ} \mathrm{C}$ for $10 \mathrm{~min}$ (Fu et al., 2013), and cooled to room temperature (around $20^{\circ} \mathrm{C}$ ) before inoculated with LAB inoculum.

\subsection{Measurement of the rheological property of RSM}

The rheological property of RSM media with different solids contents was determined using a rotational rheometer (Kinexus pro+, Malvern, UK) equipped with parallel plates $(\Phi=40 \mathrm{~mm}$, gap $=0.154 \mathrm{~mm})$. The measurements were performed at $25{ }^{\circ} \mathrm{C}$ on freshly prepared RSM without autoclave. The flow characteristics of each RSM medium were determined by recording the shear stress at increasing shear rates from 0.1 to $100 \mathrm{~s}^{-1}$.

\subsection{Cultivation of LAB in RSM media with different solids contents}

The 12-h inoculum of each LAB strain was used to inoculate autoclaved RSM media at an inoculum size of $1 \%(\mathrm{v} / \mathrm{v})$, using $5.0 \mathrm{wt} \% \mathrm{MRS}$ broth as control. The four strains were individually cultured in a stationary incubator at $37{ }^{\circ} \mathrm{C}$. The growth curves of LCZ and LGG in different media were monitored, by taking samples every 6 or $12 \mathrm{~h}$ and analyzing the viable cell count with the standard plate count method (Zheng et al., 2015) till $96 \mathrm{~h}$ of incubation.

For heat treatment experiments, LAB cultures were incubated in the RSM media for $36 \mathrm{~h}$ and in the MRS broth for $24 \mathrm{~h}$. The time of incubation was selected as the time when each strain reached the stationary growth phase according to the measured growth curve. The $\mathrm{pH}$ of the $\mathrm{LAB}$ cultures at the stationary phase was determined with a $\mathrm{pH}$ meter (Orion Star A211, Thermo Scientific, US), after thoroughly mixing each culture by vortexing (Poxiwar, China).

\subsection{Heat treatment of $L A B$ cultures}

\subsubsection{Heat treatment}

LAB cultures after incubation in the RSM media for $36 \mathrm{~h}$ and in the MRS broth for $24 \mathrm{~h}$ were subjected to heat treatment. After vortexing, 5 $\mathrm{mL}$ of each culture was transferred to a $50 \mathrm{~mL}$ centrifuge tube. Two tubes were prepared for each culture. One of them served as the unheated sample, while the other tube was placed into a thermal mixer (Eppendorf, Germany) preheated to either $65{ }^{\circ} \mathrm{C}$ or $70{ }^{\circ} \mathrm{C}$. The time of heat treatment was controlled as $10 \mathrm{~min}$ according to the result of preliminary experiments. The sample tubes were immediately taken out after $10 \mathrm{~min}$ and placed in an ice bath for $1 \mathrm{~min}$, before further analysis. The temperature change of the LAB cultures during the heat treatment was monitored using a micro-thermocouple inserted through the cap of the 50-mL centrifuge tube. Under the tested heating scheme, each culture experienced an increase in temperature (Fig. 1) to mimic the temperature profile of atomized droplets during spray drying (Huang et al., 2014; Rogers et al., 2012). 


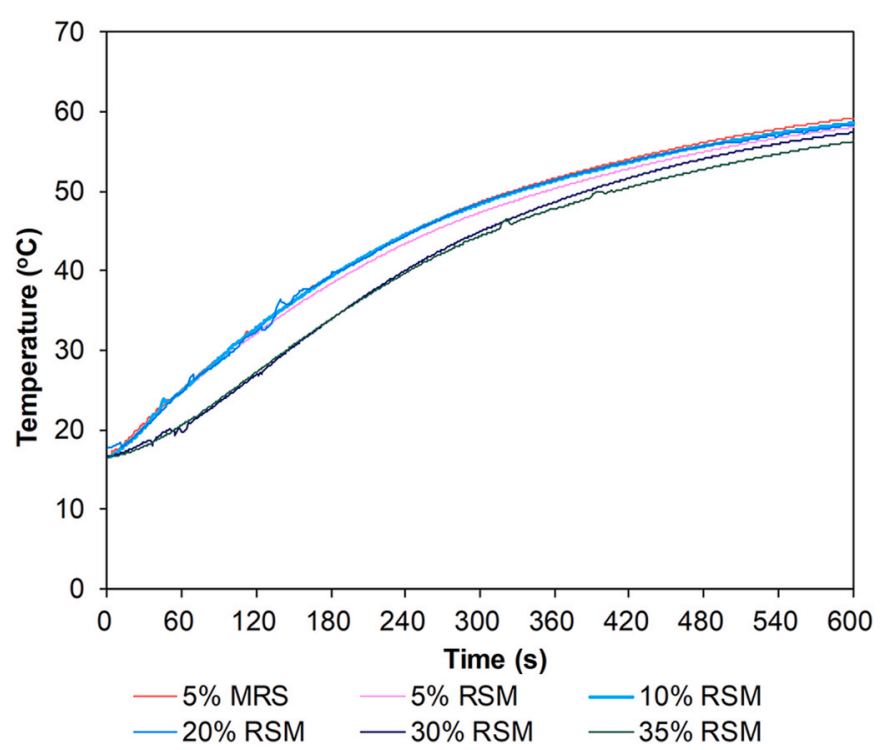

Fig. 1. The temperature curves of LCZ cultures grown in reconstituted skim milk (RSM) with different solids contents (wt\%) during heat treatment at $65^{\circ} \mathrm{C}$. The size of each culture was $5 \mathrm{~mL}$, placed in a $50 \mathrm{~mL}$ centrifuge tube. Each curve represents the average results of duplicate measurements.

\subsubsection{Analyses on the survival and growth capability of $L A B$ after heat treatment}

After heat treatment for $10 \mathrm{~min}$, the viable cell count in each sample was determined by the plate count method on MRS agar. The survival of bacteria was expressed as $N / N_{0}$, where $N$ was the remaining bacterial population after the heat treatment and $N_{O}$ represented the population in the untreated sample.

The impairment of the growth capability of LAB cells by the heat treatment was also monitored (Su et al., 2019). The heated and unheated cultures were inoculated to $1 \mathrm{~mL}$ of fresh MRS broth in a 48-well microplate, at an inoculum size of $1 \%(\mathrm{v} / \mathrm{v})$. The microplate was incubated at $37^{\circ} \mathrm{C}$ for $48 \mathrm{~h}$, and the optical density of each inoculated well was read at $600 \mathrm{~nm}$ at an interval of $20 \mathrm{~min}$ using a microplate reader (SpectraMax M5, Molecular Devices, CA, USA).

\subsection{Statistical analysis}

All the culture and heat treatment experiments were independently performed at least three times. The results of viable cell count, survival ratio and $\mathrm{pH}$ were presented as mean values \pm standard deviation. Significant differences $(p<0.05)$ between mean values were analyzed using one-way ANOVA with post hoc Tukey's test (Origin, OriginLab). The growth capability experiments were carried out in duplicate, and the reported growth curve represented the average result.

\section{Results and discussion}

\subsection{The rheological property of RSM with different solids contents}

Fig. 2 shows the flow curves of freshly prepared RSM. The media with solids content $\leq 20 \mathrm{wt} \%$ demonstrated nearly linear relationship between shear stress and shear rate, indicating that they can be considered as Newtonian liquid. Increasing the total solids of milk remarkably increased the shear stress at the same shear rate, corresponding to a higher medium viscosity. The maximum shear stress at $100 \mathrm{~s}^{-1}$ was $3.19 \mathrm{~Pa}$ for $40 \mathrm{wt} \%$ RSM, nearly 3 fold as high as that of 30 wt $\%$ RSM. A larger gap was observed between RSM with 30 and $40 \mathrm{wt} \%$ solids, compared to the media with lower solids content, suggesting that the increase in the milk viscosity was not proportional to the increase of solids content. RSM with 30 and $40 \mathrm{wt} \%$ solids exhibited shear-thinning
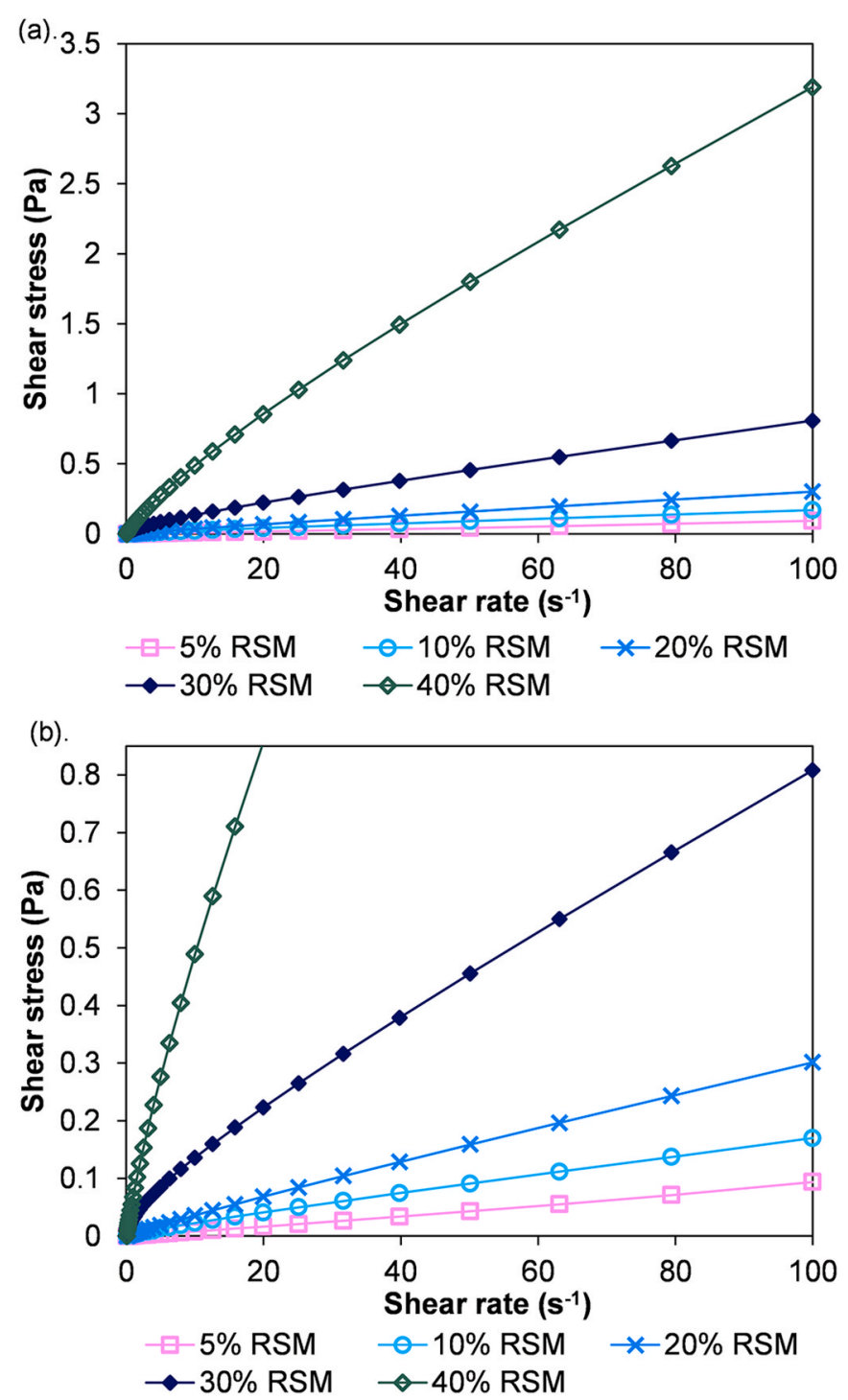

Fig. 2. Flow curves of freshly reconstituted skim milk (RSM) with different solids contents (wt\%). (a) Stress range between 0 and $3.5 \mathrm{~Pa}$; (b) stress range between 0 and $0.8 \mathrm{~Pa}$.

behavior, which was a common observation for milk protein solution with a relatively high solids content (Kieferle et al., 2019). After autoclaving at $105{ }^{\circ} \mathrm{C}$ for $10 \mathrm{~min}$, RSM with solids content $\leq 35 \mathrm{wt} \%$ could remain fluid, but $40 \mathrm{wt} \%$ milk demonstrated gel-like properties, which could be a result of the intensive Maillard reaction and protein-protein interactions during heating (Kieferle et al., 2019). The growth of bacterial cells in the semi-solid-state fermentation may be different from that in the submerged fermentation. In addition, feed material in a liquid state is relatively easier in processing and transferring than that in a semi-solid state for many industrial operations such as spray drying. Therefore, RSM with $40 \mathrm{wt} \%$ and higher solids content was not used for culturing LAB cells in this study.

\subsection{Growth of LAB in RSM with different solids contents}

The effect of the concentration of RSM on the growth of LAB was investigated with LCZ and LGG (Fig. 3). Compared to cultures grown in MRS broth, LAB grown in the milk media demonstrated a delay in reaching stationary growth phase and an extension of the duration of the stationary phase. Taking LCZ as an instance, the viable cell count in the MRS broth reached around $8.80 \times 10^{8} \mathrm{CFU} / \mathrm{mL}$ after $24 \mathrm{~h}$ of incubation, 


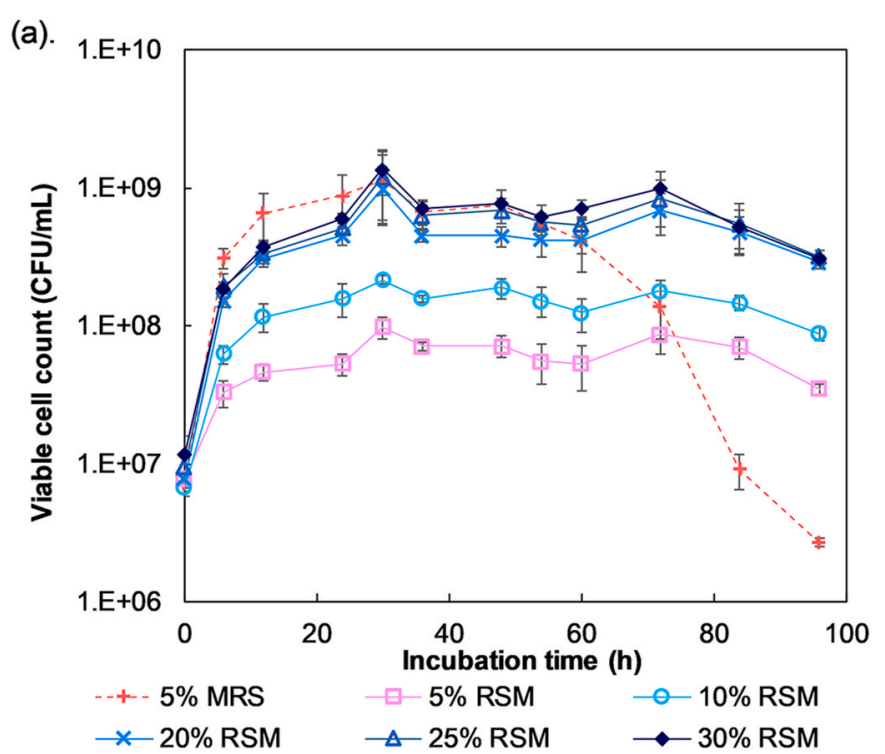

(b).

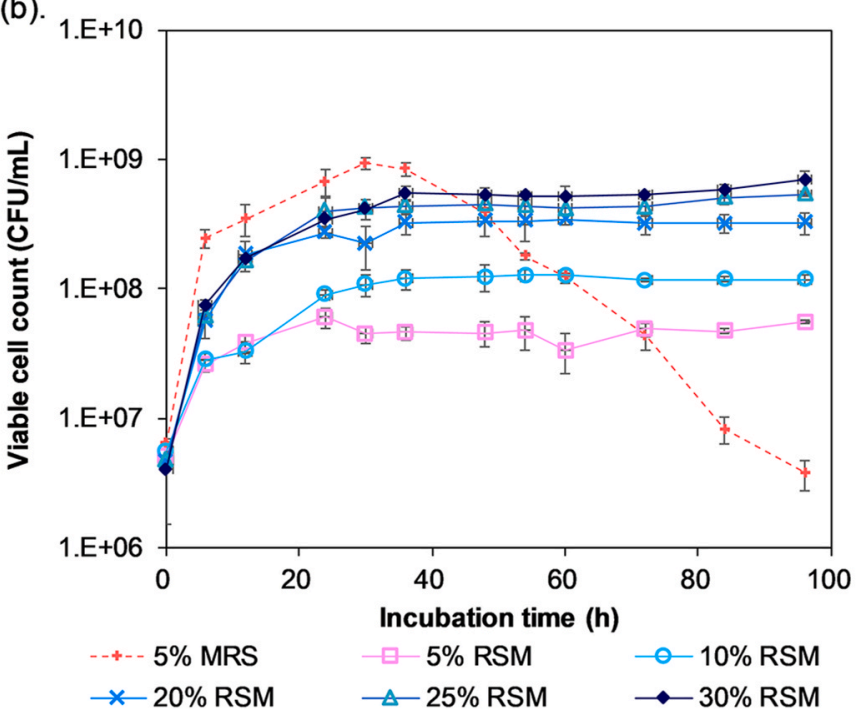

Fig. 3. The growth curves of (a) LCZ and (b) LGG when cultured in reconstituted skim milk (RSM) with different solids contents (wt\%), compared to when cultured in the standard growth medium, MRS.

and then leveled off for approximately $24 \mathrm{~h}$, followed by a rapid decrease for more than two orders of magnitude in the subsequent $48 \mathrm{~h}$ (Fig. 3a). By contrast, the viable cell count of LCZ in all types of milk media could remain around the peak value with only slight decrease till the end of incubation for $96 \mathrm{~h}$. The population of viable LCZ at the stationary growth phase increased with the increase in the solids content of RSM. LCZ cultured in $5 \mathrm{wt} \%$ milk showed a viable cell concentration around $5.32 \times 10^{7}-9.84 \times 10^{7} \mathrm{CFU} / \mathrm{mL}$ between 24 and $96 \mathrm{~h}$ of incubation, whereas the bacterial population was remarkably increased to $5.25 \times 10^{8}-1.39 \times 10^{9} \mathrm{CFU} / \mathrm{mL}$ when 25 and $30 \mathrm{wt} \%$ RSM were used. LGG cultures showed similar trends on the delayed occurrence of stationary phase and the increased cell population with a higher milk concentration (Fig. 3b). Both LCZ and LGG are non-lactose-fermenting strains (Saxelin, 1997; Wu et al., 2009). The inability to directly utilize lactose, which was the main carbohydrate in RSM, as carbon source likely resulted in the slow growth and low viable cell count for cells cultured in the low solids RSM. The growth of bacteria might rely on milk proteins serving as both carbon source and nitrogen source; meanwhile, other energy sources in the milk may be utilized, such as glucose, citrate, fatty acids, etc. (Williams et al., 2000). In the high solids
RSM, the rich nutrient might have benefited the biomass production of LCZ and LGG.

The extended stationary phase of LAB cultured in RSM could be linked to the low degree of nutrient starvation and the low acidity of medium. The main carbon source in MRS broth was glucose, which was readily assimilated and easily utilized by the bacteria (De Man et al., 1960; Gomes et al., 2018). The resulting metabolite, lactic acid, quickly lowered the $\mathrm{pH}$ of the medium to around 3.67 after $24 \mathrm{~h}$ culture of LCZ in the present study (Fig. 4). LAB cells in such an environment gradually entered the death phase (Fig. 3a), resulting from the depletion of nutrients and the accumulation of acid stress. By contrast, all types of RSM media inoculated with LCZ showed $\mathrm{pH}$ values higher than 5.80 after 36 $\mathrm{h}$ of incubation, when the culture was ready for the subsequent heat treatment (Fig. 4). The pH of autoclaved RSM decreased from 6.75 to 6.02 with the increase of solids content from $5 \mathrm{wt} \%$ to $35 \mathrm{wt} \%$. The fermentation by LCZ for $36 \mathrm{~h}$ caused a $\mathrm{pH}$ reduction less than 0.30 for all types of RSM tested, indicating the incapacity of the strain to consume lactose (Saxelin et al., 1999). The slow consumption of milk components might allow the medium to support the growth and metabolism of bacterial cells for an extended period. In addition, skim milk showed better buffering capacity than MRS owing to milk components such as proteins, free amino acids, and some weak acids and bases (Upreti et al., 2006), which could help maintain a relatively stable $\mathrm{pH}$ for LAB cells to survive.

High solids milk appeared to provide a more stable $\mathrm{pH}$ environment than low solids milk when fermented with LCBL23, which was a lactosefermenting strain (Fig. 4). LCBL23 at the stationary growth phase decreased the $\mathrm{pH}$ of $5 \mathrm{wt} \%$ MRS broth, $5 \mathrm{wt} \%$ RSM and $35 \mathrm{wt} \%$ RSM by $2.07,1.35$ and 0.16 , respectively. Nevertheless, after $36 \mathrm{~h}$ of incubation, the $\mathrm{pH}$ of different types of RSM was maintained between 5.41 and 5.86, which was within the range of low-acid foods $(\mathrm{pH}>4.6)$ (Silva and Gibbs, 2010).

High solids RSM could exert higher osmotic stress on LAB cells than MRS, because of the decreased water activity (Mille et al., 2004). However, the high viable cell concentration observed in the present study suggested that the growth of bacteria was minimally affected. Bacterial cells grown in high osmolality environment may activate stress response network and accumulate compatible solutes either by synthesis

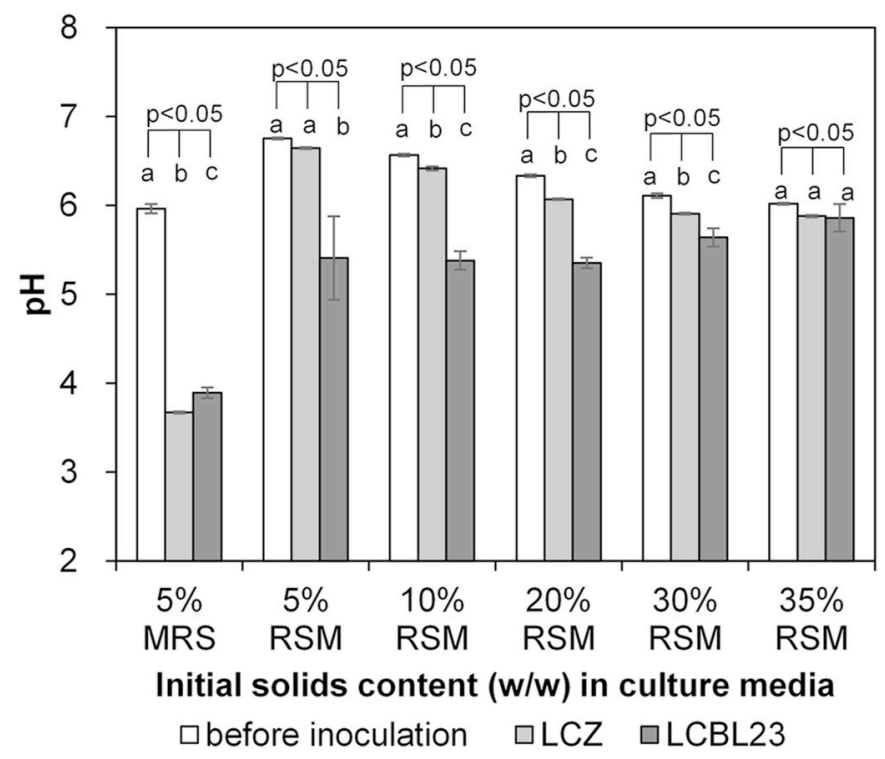

Fig. 4. The $\mathrm{pH}$ change of growth medium when LCZ and LCBL23 were cultured in 5\% MRS broth and in RSM media with different solids contents (wt\%). pH was measured after $24 \mathrm{~h}$ incubation in MRS broth and after $36 \mathrm{~h}$ incubation in each RSM media. For each type of media, different lowercase letters between autoclaved medium without inoculation, the LCZ culture and the LCBL23 culture indicate that the values are significantly different $(p<0.05)$. 
per se or by uptake from medium (Corcoran et al., 2008; Huang et al., 2016b; Sunny-Roberts and Knorr, 2009). The comparatively long growth time would allow LAB cells to adapt to the high osmolality and replicate.

\subsection{Heat treatment of $L A B$ cultured in RSM with different solids contents}

\subsubsection{Survival of $L A B$ after heat treatment}

LCZ, LGG, LP and LCBL23 cultured in the RSM media for $36 \mathrm{~h}$ and in the MRS broth for $24 \mathrm{~h}$ were immediately subjected to heat treatment at $65{ }^{\circ} \mathrm{C}$ for $10 \mathrm{~min}$. The viable cell counts before and after the heat treatment are shown in Fig. 5. As the solids content of RSM was increased from $5 \mathrm{wt} \%$ to $30 \mathrm{wt} \%$, the residual viable cells of LCZ after heat treatment significantly increased from around $1.12 \times 10^{5} \mathrm{CFU} / \mathrm{mL}$ to $4.71 \times 10^{8} \mathrm{CFU} / \mathrm{mL}(p<0.05$, Fig. $5 \mathrm{a})$. When the solids content was further increased to $35 \mathrm{wt} \%$, a decline in cell survival was observed, with residual viability around $1.05 \times 10^{8} \mathrm{CFU} / \mathrm{mL}$ in the heat-treated sample. After heating at $65^{\circ} \mathrm{C}$ for $10 \mathrm{~min}$, the viable population of LCZ in the 20 , 30 and $35 \mathrm{wt} \% \mathrm{RSM}$ was all greater than or equal to $1 \times 10^{8} \mathrm{CFU} / \mathrm{mL}$. By contrast, the viable cell count was significantly decreased to around $1.19 \times 10^{5} \mathrm{CFU} / \mathrm{mL}$ in the control culture of LCZ with MRS as growth medium. The highest survival of LCZ, which was achieved with $30 \mathrm{wt} \%$ RSM, was approximately 811-fold as high as the survival observed for the $5 \mathrm{wt} \%$ RSM culture (survival ratios of $73 \%$ and $0.09 \%$, respectively, Fig. 6).

LGG, LP and LCBL32 were cultured in RSM media with selected solids contents, namely 5, 20 and $30 \mathrm{wt} \%$, using $5 \mathrm{wt} \%$ MRS broth as
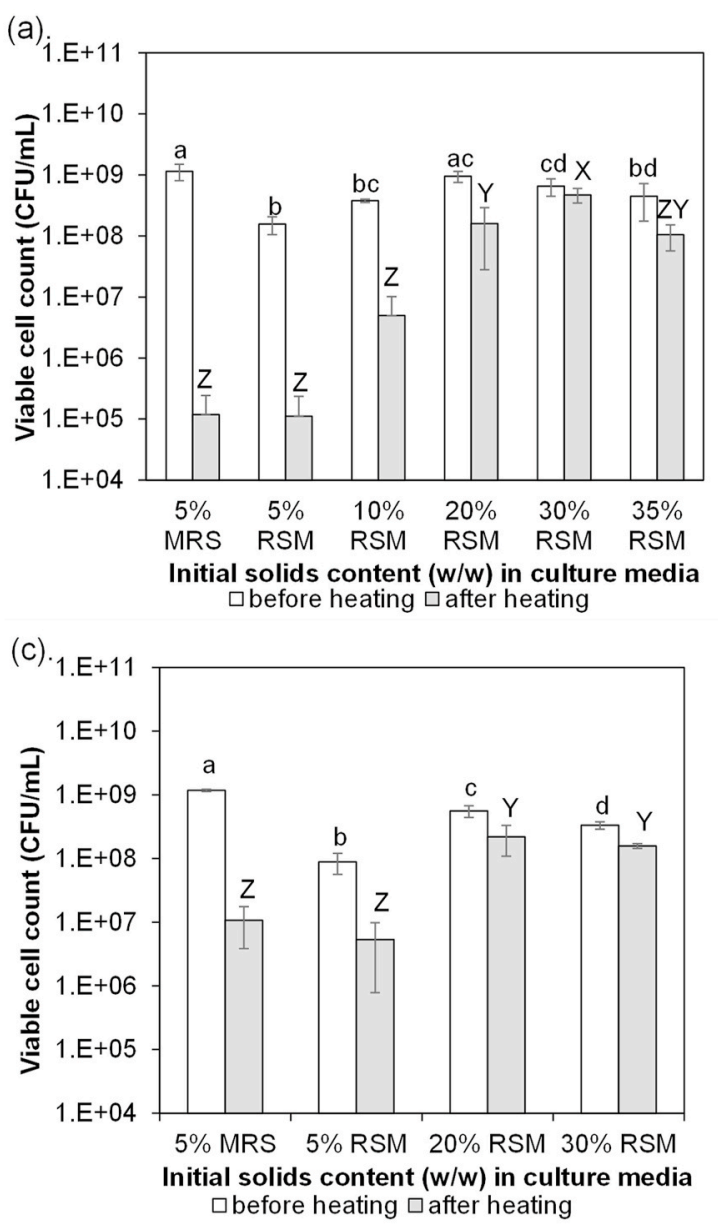

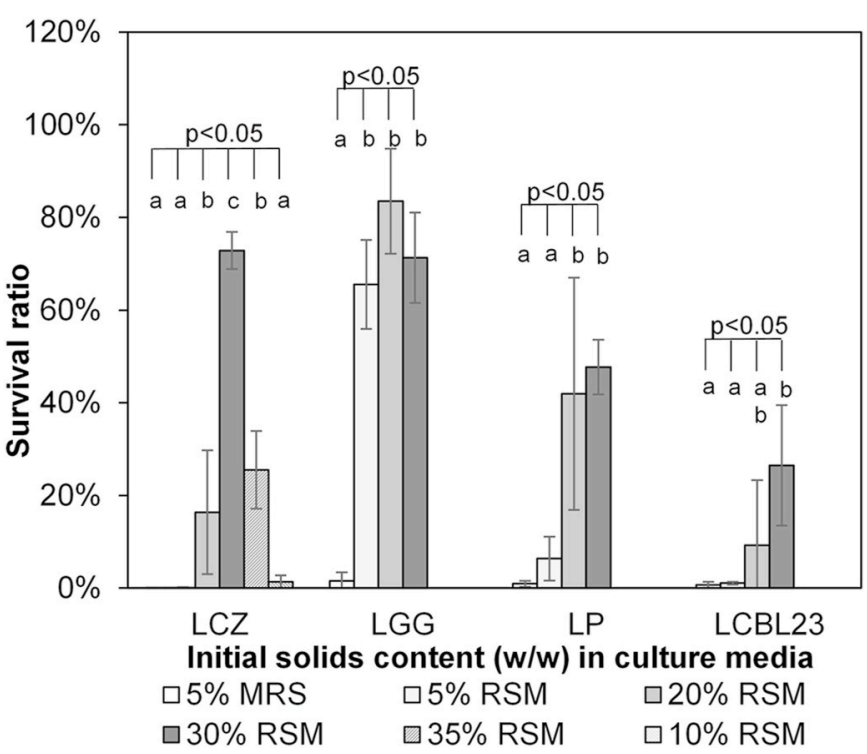

Fig. 6. The survival ratios of LCZ, LGG, LP and LCBL23 cultured in reconstituted skim milk (RSM) with different solids contents (wt $\%$ ), after heat treatment at $65{ }^{\circ} \mathrm{C}$ for $10 \mathrm{~min}$. Different lowercase letters for the same strain indicate that the values are significantly different $(p<0.05)$.

(b).
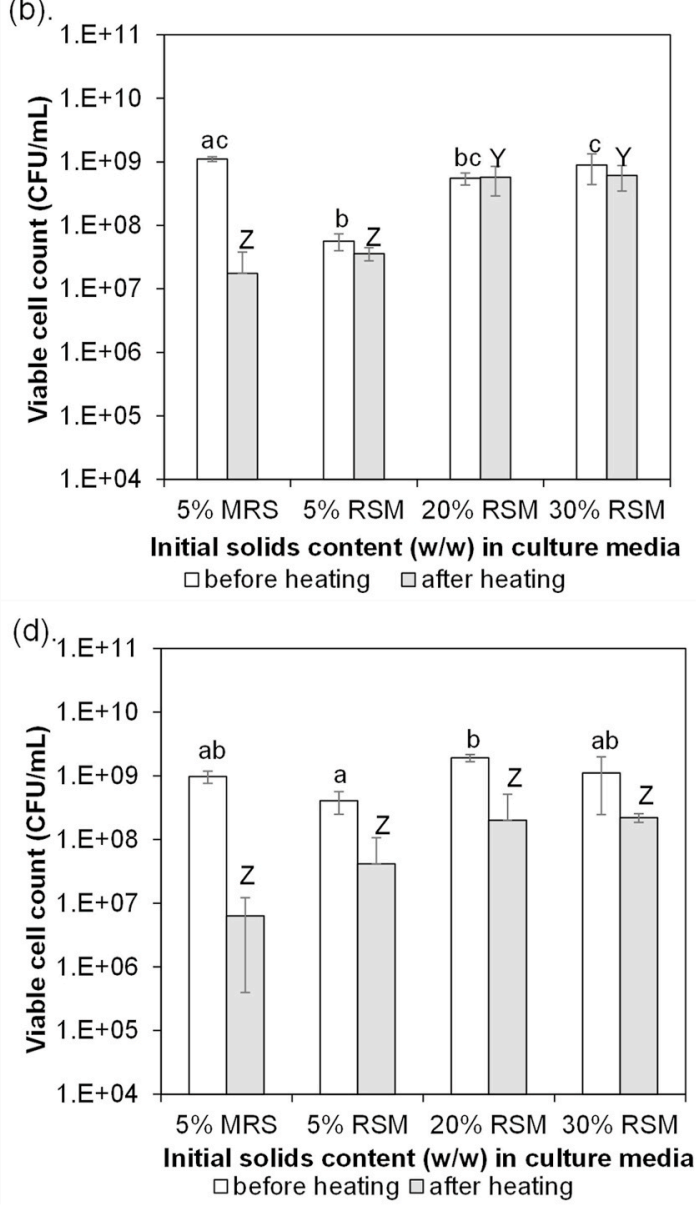

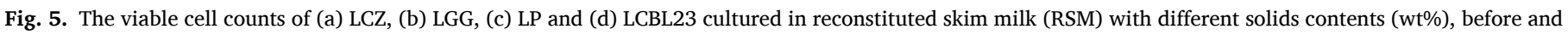

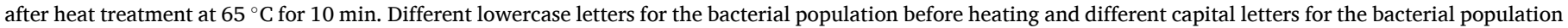
after heating indicate that the values are significantly different $(p<0.05)$. 
control. The viable cell counts of the three strains in the 36-h culture were similar to LCZ, ranged between $1 \times 10^{8}$ and $1 \times 10^{9} \mathrm{CFU} / \mathrm{mL}$ (Fig. 5b-d). After heat treatment for $10 \mathrm{~min}$, the population of LGG in the 20 and $30 \mathrm{wt} \% \mathrm{RSM}$ remained close to $1 \times 10^{9} \mathrm{CFU} / \mathrm{mL}$, which was approximately 1-2 orders of magnitude higher than the population remaining in the two types of low solids media ( $p<0.05$, Fig. $5 b)$. LP showed a similar trend in the residual viability after heating between different types of media, but its survival ratio was generally lower than LGG (Fig. 6). The remaining viable cells and the survival of LCBL23 in the RSM media with 20 wt $\%$ solids content were not significantly different from that in the $5 \mathrm{wt} \%$ RSM and MRS (Figs. 5d and 6). By contrast, $30 \mathrm{wt} \%$ RSM demonstrated better protection on the survival of LCBL23 after heat treatment (26.5\%) than $5 \mathrm{wt} \%$ RSM and MRS $(0.71 \%$ and $1.07 \%$, respectively; $p<0.05$ ), but the result of $30 \mathrm{wt} \%$ RSM was not significantly different from that of $20 \mathrm{wt} \%$ (9.25\%, Fig. 6).

Although the optimal solids content for enhancing the survival of individual LAB after heat treatment was species- and strain-specific, 20 and $30 \mathrm{wt} \%$ generally demonstrated a beneficial effect compared to the media with lower solids content. At this concentration range of milk, the residual viability of all four strains were higher than $1 \times 10^{8} \mathrm{CFU} / \mathrm{mL}$ after heating at $65{ }^{\circ} \mathrm{C}$ for $10 \mathrm{~min}$. The results indicated a substantially improved thermotolerance of $\mathrm{LAB}$, in comparison to lactobacilli cultured in MRS broth and transferred to $20 \mathrm{wt} \% \mathrm{RSM}$ or $20 \mathrm{wt} \%$ trehalose media for heat challenging in previous studies (Corcoran et al., 2004; Sunny-Roberts and Knorr, 2009).

The effect of the increased RSM concentration on enhancing the heat stability of LAB was further confirmed by the heat treatment of LGG at $70{ }^{\circ} \mathrm{C}$ for $10 \mathrm{~min}$ (Fig. 7). The high temperature effectively deactivated the bacteria to a viability range between $10^{6}$ and $10^{7} \mathrm{CFU} / \mathrm{mL}$ in all four types of culture media. Nevertheless, LGG cells grown in the $20 \mathrm{wt} \%$ RSM once again showed a high survival of $4.4 \%$, which was one order of magnitude higher than the survival observed for cells grown in $5 \mathrm{wt} \%$ RSM or MRS $(<0.5 \%)$.

Among the four strains tested, LGG demonstrated the best heat stability with survival ratios higher than $60 \%$ in all three types of RSM media after heat treatment at $65^{\circ} \mathrm{C}$ (Fig. 6). The heat stability of LCZ and LP was inferior to LGG, but better than LCBL23, whose survival ratios were $<30 \%$ regardless of the growth medium used. Note that both LP and LCBL23 were capable of fermenting lactose and yielding lactate as the main metabolite. Previous studies showed that L. plantarum is one of the species that demonstrate a high resistance to heat and osmotic

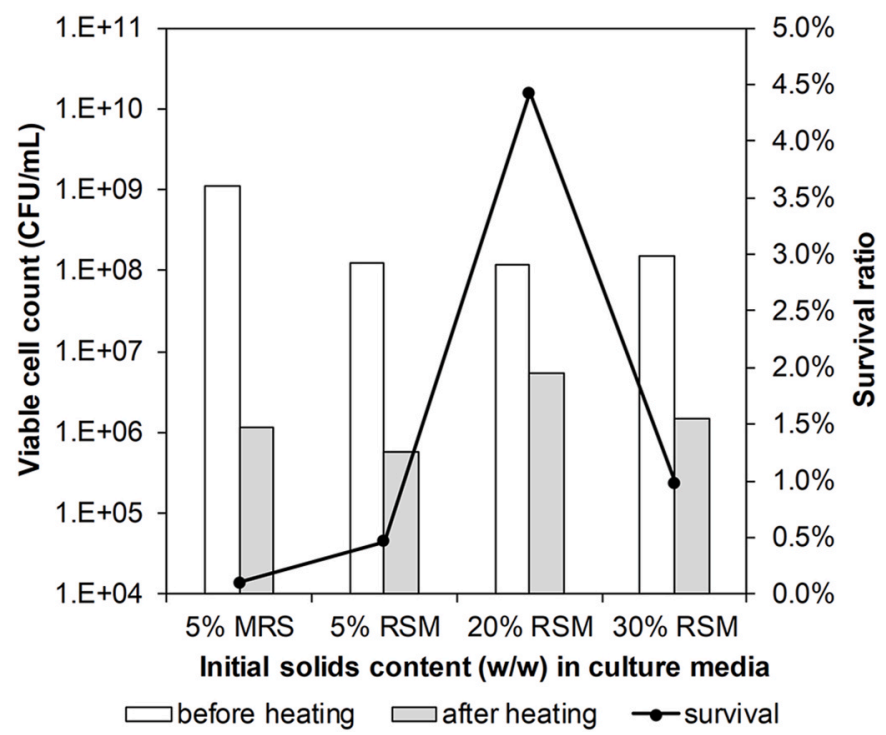

Fig. 7. The viable cell counts (left $Y$ axis) and survival ratios (right $Y$ axis) of LGG cultured in reconstituted skim milk (RSM) with different solids contents (wt\%), after heat treatment at $70{ }^{\circ} \mathrm{C}$ for $10 \mathrm{~min}$. stresses (Bucio et al., 2005; Golowczyc et al., 2010). LGG was relatively heat sensitive compared to Lactobacillus rhamnosus E800 and Lactobacillus salivarius UCC 500, but its survival during spray drying, which involved multiple stresses, was comparable to or better than these two strains (Corcoran et al., 2004). Despite the different biological properties and metabolic pathways shown by the four strains, culturing individual LAB in the RSM with increased solids content led to a general improvement of thermotolerance.

\subsubsection{Influence of heat treatment on the growth capability of $L A B$}

The growth capability of LAB in liquid culture influences the colonization of cells in intestinal tract. The comparison of the growth capability of the four LAB before and after heat treatment at $65{ }^{\circ} \mathrm{C}$ is made in Fig. 8. The four strains demonstrated similar trends in growth behavior, when fresh 36-h culture grown in different media was inoculated to rich MRS medium. For unheated samples, cells grown in $5 \mathrm{wt} \%$ MRS quickly entered exponential growth phase, as a result of the high viable cell level in the culture (Fig. 5). By contrast, cells from the $5 \mathrm{wt} \%$ RSM medium, which contained the lowest viable cell count among the different culture media, showed a prolonged lag phase before the beginning of exponential growth (Fig. 8a-d). Heat treatment at $65{ }^{\circ} \mathrm{C}$ caused an extension of lag phase for all four strains cultured in all types of media, indicating the impairment of growth capability (Fig. 8A-D). Nevertheless, LCZ, LGG and LCBL23 cultured in the $30 \mathrm{wt} \% \mathrm{RSM}$ retrieved the capability of exponential growth at the shortest time compared to their respective counterparts cultured in other media. LP cells from the $20 \mathrm{wt} \%$ RSM demonstrated the shortest lag phase, which was closely followed by the $30 \mathrm{wt} \%$ RSM culture.

The time when the optical density of the culture reached 1 (the intersection between each growth curve and the time axis in Fig. 8) was compared between the unheated and the heated samples for each LAB strain cultured in the 5 and $30 \mathrm{wt} \%$ RSM media. Denoting the time achieved with unheated culture as $t_{0}$ and that with heated culture as $t_{1}$, the difference between $t_{1}$ and $t_{0}(\Delta t)$ partly reflected the degree of damage on the growth capability caused by the heat treatment. It can be seen from Table 1 that heat treatment caused a delay in the rapid bacterial growth, ranged between 3.17 and $7.00 \mathrm{~h}$ for LAB cells grown in the $5 \mathrm{wt} \%$ RSM. By contrast, the difference before and after heat treatment for the LAB cultures grown in the $30 \mathrm{wt} \%$ RSM was smaller, ranged between 0.50 and $3.50 \mathrm{~h}$.

Changes in the growth capability of LAB cells after heat treatment were in agreement with the above results on cell survival. Culturing LAB with high solids RSM, $30 \mathrm{wt} \%$ in particular, exerted substantial protective effect on the growth capability of cells towards heat stress, which could be attributed to two reasons. First, with $30 \mathrm{wt} \% \mathrm{RSM}$, the viable cells remaining in the heated culture was at a high level (Fig. 5), which, for example, reached $4.71 \times 10^{8} \mathrm{CFU} / \mathrm{mL}$ for LCZ in $30 \mathrm{wt} \% \mathrm{RSM}$, compared to $1.12 \times 10^{5} \mathrm{CFU} / \mathrm{mL}$ obtained with $5 \mathrm{wt} \% \mathrm{RSM}$. The high level of viable cells in the inoculum undoubtedly shortened the lag phase during the re-growth experiments. Second, there might be a part of injured cell population that could not replicate on the solid MRS agar, but was able to repair the injuries and continue multiplying in the rich liquid broth.

\subsection{Mechanisms for the enhanced thermotolerance of $L A B$ cultured in the high solids RSM}

The comparison on the survival and growth capability between heattreated LAB cultures from different culture media demonstrated the excellent thermotolerance of cells grown in the high solids RSM with 20 and $30 \mathrm{wt} \%$ solids content. The highly concentrated growth environment with reduced water activity may allow the bacterial cells to respond to the osmotic stress by adjusting their metabolic flow and genetic expression. The activated cellular stress response could exert crossprotective effect towards multiple stresses (Desmond et al., 2001; Dijkstra et al., 2014), which was manifested as LAB acquiring tolerance 
(a).

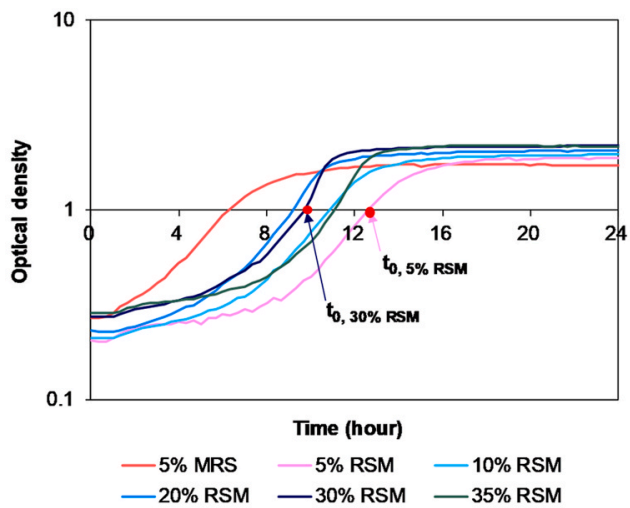

(b).

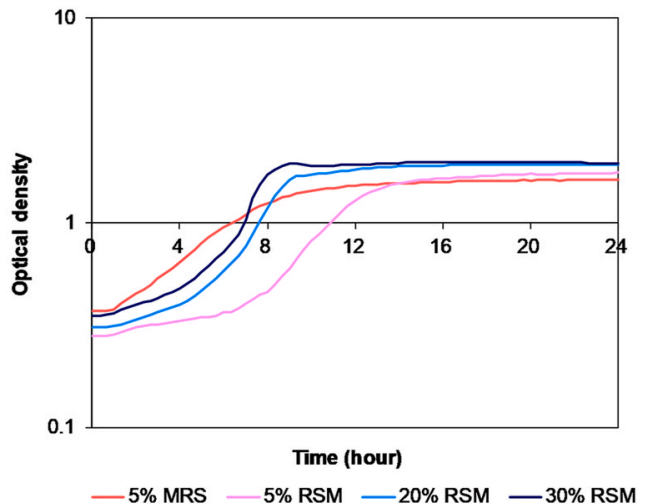

(c).

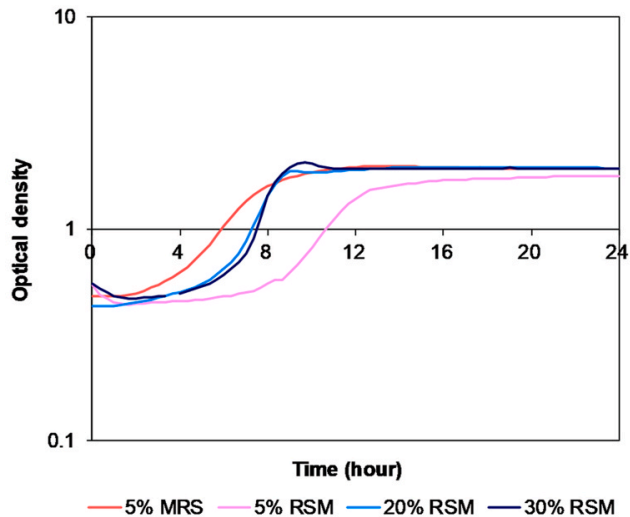

(d).

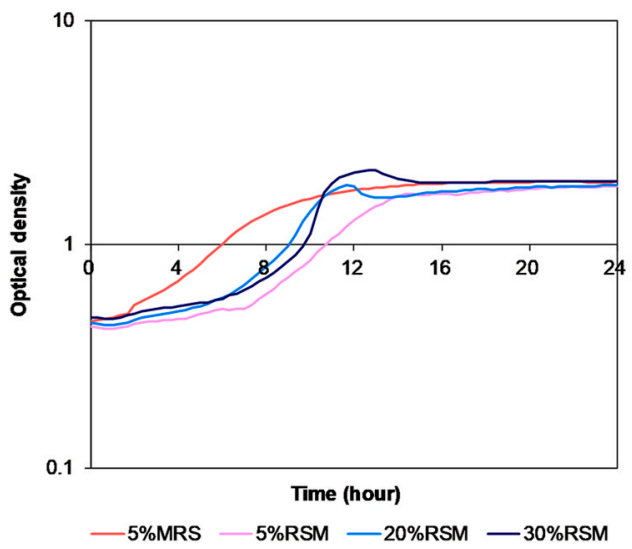

(A).

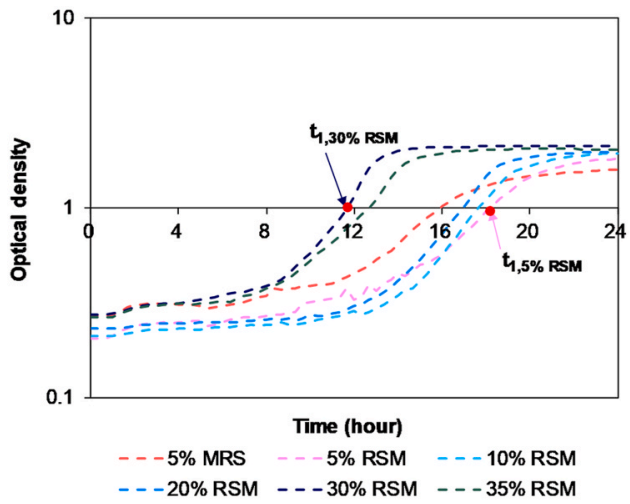

(B).

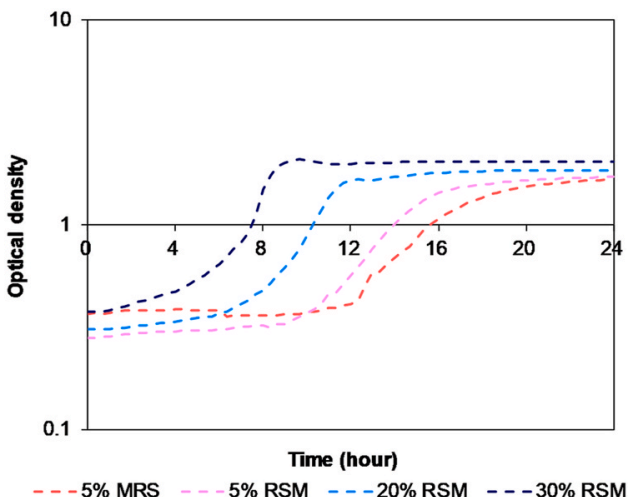

(C).

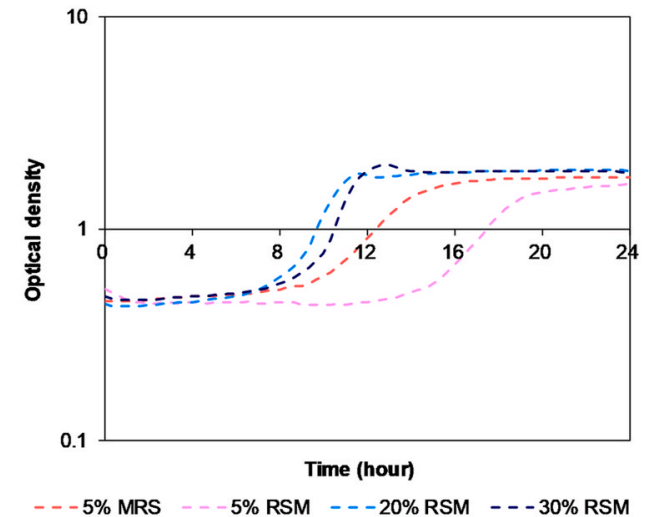

(D)

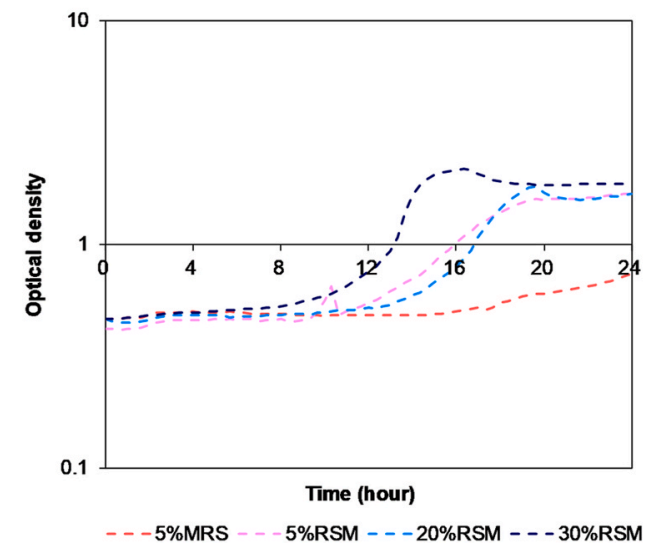

$---5 \%$ MRS - $-5 \%$ RSM - - $-20 \%$ RSM - - $30 \%$ RSM
Fig. 8. The growth capability of (a, A) LCZ, (b, B) LGG, (c, C)) LP and (d, D) LCBL23 in rich MRS broth, as influenced by the different types of growth media used to culture the inoculum. (a-d) The growth curves before the heat treatment of each inoculum; (A-D) the growth curves after the heat treatment of each inoculum at $65{ }^{\circ} \mathrm{C}$ for $10 \mathrm{~min} . t_{0}$ and $t_{1}$ show the time when the optical density of the MRS broth reached 1 , before and after heat treatment, respectively. Each curve represents the average results of duplicate experiments. 
Table 1

The time when the optical density of different types of MRS broth, which were inoculated with LAB strains grown in $5 \mathrm{wt} \%$ and $30 \mathrm{wt} \% \mathrm{RSM}$, reached 1.

\begin{tabular}{|c|c|c|c|c|c|c|c|}
\hline \multirow[t]{2}{*}{ Strains } & \multicolumn{3}{|c|}{5 wt $\%$ RSM } & \multicolumn{3}{|c|}{$30 \mathrm{wt} \%$ RSM } & \multirow{2}{*}{$\begin{array}{l}\text { Ratio } \\
\left(\Delta \mathrm{t}_{30 \%}\right. \\
\text { RSM } / \Delta \mathrm{t}_{5 \%} \\
\text { RSM })\end{array}$} \\
\hline & $t_{0}(\mathrm{~h})^{\mathrm{a}}$ & $t_{1}(\mathrm{~h})^{\mathrm{a}}$ & $\begin{array}{l}\Delta t \\
(\mathrm{~h})^{\mathrm{b}}\end{array}$ & $t_{0}(\mathrm{~h})$ & $t_{1}(\mathrm{~h})$ & $\begin{array}{l}\Delta t \\
\text { (h) }\end{array}$ & \\
\hline LCZ & $\begin{array}{l}12.84 \\
\pm 0.01\end{array}$ & $\begin{array}{l}18.33 \\
\pm 0.00\end{array}$ & 5.49 & $\begin{array}{l}9.84 \pm \\
0.02\end{array}$ & $\begin{array}{l}11.67 \\
\pm 0.01\end{array}$ & 1.83 & 0.33 \\
\hline LGG & $\begin{array}{l}11.00 \\
\pm 0.00\end{array}$ & $\begin{array}{l}14.17 \\
\pm 0.01\end{array}$ & 3.17 & $\begin{array}{l}7.17 \pm \\
0.02\end{array}$ & $\begin{array}{l}7.67 \pm \\
0.00\end{array}$ & 0.50 & 0.16 \\
\hline LP & $\begin{array}{l}10.67 \\
\pm 0.03\end{array}$ & $\begin{array}{l}17.67 \\
\pm 0.00\end{array}$ & 7.00 & $\begin{array}{l}7.67 \pm \\
0.00\end{array}$ & $\begin{array}{l}10.67 \\
\pm 0.00\end{array}$ & 3.00 & 0.43 \\
\hline LCBL23 & $\begin{array}{l}11.00 \\
\pm 0.00\end{array}$ & $\begin{array}{l}16.17 \\
\pm 0.01\end{array}$ & 5.17 & $\begin{array}{l}10.00 \\
\pm 0.00\end{array}$ & $\begin{array}{l}13.50 \\
\pm 0.01\end{array}$ & 3.50 & 0.68 \\
\hline
\end{tabular}

${ }^{\mathrm{a}} t_{0}$ and $t_{1}$ represented the time when each growth curve in Fig. 8 intersected with the time axis, before and after the heat treatment at $65{ }^{\circ} \mathrm{C}$ for $10 \mathrm{~min}$, respectively. Each value was presented as average \pm percentage error of duplicate experiments.

b $\Delta t=t_{1}-t_{0}$.

against heat stress in this study. Heat stress can affect a large number of regions and key processes associated with microbial activity and growth. For instance, fatty acids on cell membrane are susceptible to thermal damage, and essential intracellular structures such as ribosomes may be degraded (Somero, 1995; Teixeira et al., 1997). The activation of heat shock proteins such as GroES, GroEL (Desmond et al., 2004; Savijoki et al., 2005), DnaK (Prasad et al., 2003; Savijoki et al., 2005) and proteases such as HtrA (Savijoki et al., 2005) could mitigate the heat-induced cellular damages and help LAB cells survive the stress. Huang et al. (2018) found that growing LCBL23 in 30\% sweet whey triggered multiple stress tolerance. The resulting cells over-expressed many proteins, including proteins related to translation, ribosomal structure and protein synthesis, structural proteins on cell wall/membrane/envelope, as well as heat shock proteins such as groS and DnaK. The use of high solids RSM in the present study may have a similar effect in activating the stress-response network of LAB cells.

Besides the cellular adaptation effect arisen from the increased osmotic pressure, the concentration of protective agents in the high solids RSM was also higher than that in the low solids RSM. Calcium was shown to be the critical component responsible for the thermoprotective effect of whey (Manas et al., 2001) and the baroprotective effect of micellar casein (Black et al., 2007). Aggregated milk proteins could compactly embed LAB cells and significantly improve their thermotolerance (Huang et al., 2014). The increased concentration of calcium and milk proteins in the high solids milk may help improve the thermotolerance of LAB cells.

Finally, the difference in the solids content can alter the rheological properties and thermal conductivity of RSM, which may be crucial factors contributing to the improved heat stability of LAB cells. As shown in Fig. 2, the fluidity of RSM was decreased with the increase in milk concentration. During heat treatment, the high concentration of solid matter could provide a better support in maintaining the integrity of cells, by lowering the rate of possible diffusion of intracellular substances from injured cells (Liu et al., 2018). The increased medium viscosity and the associated low mobility of molecules can help preserve the stability of proteins (Chang et al., 1996) and liposomes (Sun et al., 1996), as well as slow down the rate of chemical reactions (Karmas et al., 1992). All these properties contribute to the stabilization of biological systems. In addition, the temperature curves of the RSM with different solids contents also showed slight difference (Fig. 1), although the heating was performed under identical conditions. Compared to media with solids content $\leq 20 \mathrm{wt} \%$, RSM with 30 and $35 \mathrm{wt} \%$ solids contents showed slower temperature increase, implying lessened thermal stress imposed on LAB cells during heat treatment. The high thermal resistance of medium is a favorable property in industrial applications.

Previous studies showed that by culturing LAB in $30 \mathrm{wt} \%$ sweet whey, the resulting cells not only showed enhanced thermotolerance, but also survived better during both laboratory- and pilot-scale spray drying than cells grown in low solids medium (Huang et al., 2016a, 2017). The approach proposed in the present study, to culture LAB in 20-30 wt $\%$ RSM, could be a promising approach for industrial spray drying to produce active $\mathrm{LAB}$ powders, in which the fermentation substrate is common and ready to use.

\section{Conclusions}

This study showed that the survival and growth capability of four LAB strains after heat treatment at $65^{\circ} \mathrm{C}$ can be substantially improved by culturing cells in RSM with $20-30 \mathrm{wt} \%$ solids content. The beneficial effect was valid for all four bacterial strains with different biological properties and metabolic pathways. Compared to $20 \mathrm{wt} \% \mathrm{RSM}$, the enhancement with $30 \mathrm{wt} \%$ was more prominent, which was attributed to cellular stress response to the increased osmotic stress, the increased concentration of protective agents, and the increased viscosity and thermal resistance of the medium. The findings demonstrated the good potential of a culturing approach for further improving the protection on probiotic viability and activity in a simple and economical way. The significant improvement of the thermotolerance of LAB found in the current study also requires more scientific and systematic research at more of a molecular level, and need to be validated at the industrial application level.

\section{Author contribution statement}

Xiangshu Suo: Investigation, Visualization, Writing - Original Draft. Song Huang: Conceptualization, Supervision. Juan Wang: Investigation. Nan Fu: Methodology, Visualization, Writing - Review \& Editing, Supervision. Romain Jeantet: Supervision. Xiao Dong Chen: Conceptualization, Supervision, Funding acquisition.

\section{Declaration of competing interest}

There are no conflicts of interest to declare.

\section{Acknowledgments}

This work was supported by project funding from the National Key Research and Development Program of China (Project No. 2016YFE0101200, International S\&T Cooperation Program, ISTCP), Natural Science Foundation of China (Grant No. 31601513), and the Priority Academic Program Development (PAPD) of Jiangsu Higher Education Institutions.

\section{References}

Balthazar, C.F., Pimentel, T.C., Ferrão, L.L., Almada, C.N., Santillo, A., Albenzio, M., Mollakhalili, N., Mortazavian, A.M., Nascimento, J.S., Silva, M.C., Freitas, M.Q., Sant'Ana, A.S., Granato, D., Cruz, A.G., 2017. Sheep milk: physicochemical characteristics and relevance for functional food development. Compr. Rev. Food Sci. Food Saf. 16 (2), 247-262.

Bauerl, C., Perez-Martinez, G., Yan, F., Polk, D.B., Monedero, V., 2010. Functional analysis of the p40 and p75 proteins from Lactobacillus casei BL23. J. Mol. Microbiol, Biotechnol. 19 (4), 231-241.

Black, E.P., Huppertz, T., Fitzgerald, G.F., Kelly, A.L., 2007. Baroprotection of vegetative bacteria by milk constituents: a study of Listeria innocua. Int. Dairy J. 17 (2), 104-110.

Bucio, A., Hartemink, R., Schrama, J.W., Verreth, J., Rombouts, F.M., 2005. Survival of Lactobacillus plantarum 44a after spraying and drying in feed and during exposure to gastrointestinal tract fluids in vitro. J. Gen. Appl. Microbiol. 51 (4), 221-227.

Chang, B.S., Beauvais, R.M., Dong, A.C., Carpenter, J.F., 1996. Physical factors affecting the storage stability of freeze-dried interleukin-1 receptor antagonist: glass transition and protein conformation. Arch. Biochem. Biophys. 331 (2), 249-258.

Corcoran, B.M., Ross, R.P., Fitzgerald, G.F., Stanton, C., 2004. Comparative survival of probiotic lactobacilli spray-dried in the presence of prebiotic substances. J. Appl. Microbiol. 96 (5), 1024-1039. 
Corcoran, B.M., Stanton, C., Fitzgerald, G., Ross, R.P., 2008. Life under stress: the probiotic stress response and how it may be manipulated. Curr. Pharmaceut. Des. 14 (14), 1382-1399.

Corona-Hernandez, R.I., Alvarez-Parrilla, E., Lizardi-Mendoza, J., Islas-Rubio, A.R., de la Rosa, L.A., Wall-Medrano, A., 2013. Structural stability and viability of microencapsulated probiotic bacteria: a review. Compr. Rev. Food Sci. Food Saf. 12 (6), 614-628.

De Keersmaecker, S.C.J., Verhoeven, T.L.A., Desair, J., Marchal, K., Vanderleyden, J., Nagy, I., 2006. Strong antimicrobial activity of Lactobacillus rhamnosus GG against Salmonella typhimurium is due to accumulation of lactic acid. FEMS (Fed. Eur. Microbiol. Soc.) Microbiol. Lett. 259 (1), 89-96.

De Man, J.C., Rogosa, M., Sharpe, M.E., 1960. A medium for the cultivation of lactobacilli. J. Appl. Bacteriol. 23 (1), 130-135.

Desmond, C., Fitzgerald, G.F., Stanton, C., Ross, R.P., 2004. Improved stress tolerance of GroESL-overproducing Lactococcus lactis and probiotic Lactobacillus paracasei NFBC 338. Appl. Environ. Microbiol. 70 (10), 5929-5936.

Desmond, C., Stanton, C., Fitzgerald, G.F., Collins, K., Ross, R.P., 2001. Environmental adaptation of probiotic lactobacilli towards improvement of performance during spray drying. Int. Dairy J. 11 (10), 801-808.

Dijkstra, A.R., Alkema, W., Starrenburg, M.J.C., Hugenholtz, J., van Hijum, S.A., Bron, P. A., 2014. Fermentation-induced variation in heat and oxidative stress phenotypes of Lactococcus lactis MG1363 reveals transcriptome signatures for robustness. Microb. Cell Factories 13. Article No. 148.

FAO/WHO, 2001. Health and Nutritional Properties of Probiotics in Food Including Powder Milk with Live Lactic Acid Bacteria, pp. 1-34.

Fenster, K., Freeburg, B., Hollard, C., Wong, C., Laursen, R.R., Ouwehand, A.C., 2019. The production and delivery of probiotics: a review of a practical approach. Microorganisms 7 (3). Article No. 83.

Ferreira, V., Soares, V., Santos, C., Silva, J., Gibbs, P.A., Teixeira, P., 2005. Survival of Lactobacillus sakei during heating, drying and storage in the dried state when growth has occurred in the presence of sucrose or monosodium glutamate. Biotechnol. Lett. 27, 249-252.

Fu, N., Chen, X.D., 2011. Towards a maximal cell survival in convective thermal drying processes. Food Res. Int. 44 (5), 1127-1149.

Fu, N., Woo, M.W., Selomulya, C., Chen, X.D., 2013. Inactivation of Lactococcus lactis ssp. cremoris cells in a droplet during convective drying. Biochem. Eng. J. 79, 46-56.

Gaucher, F., Rabah, H., Kponouglo, K., Bonnassie, S., Pottier, S., Dolivet, A., Marchand, P., Jeantet, R., Blanc, P., Jan, G., 2020. Intracellular osmoprotectant concentrations determine Propionibacterium freudenreichii survival during drying. Appl. Microbiol. Biotechnol. 104, 3145-3156.

Golowczyc, M.A., Silva, J., Abraham, A.G., De Antoni, G.L., Teixeira, P., 2010. Preservation of probiotic strains isolated from kefir by spray drying. Lett. Appl. Microbiol. 50 (1), 7-12.

Gomes, T.A., Santos, L.B., Nogueira, A., Spier, M.R., 2018. Increase in an intracellular beta-galactosidase biosynthesis using L. reuteri NRRL B-14171, inducers and alternative low-cost nitrogen sources under submerged cultivation. Int. J. Food Eng. 14 (3), 20170333.

Huang, S., Cauty, C., Dolivet, A., Le Loir, Y., Chen, X.D., Schuck, P., Jan, G., Jeantet, R. 2016a. Double use of highly concentrated sweet whey to improve the biomass production and viability of spray-dried probiotic bacteria. J. Func. Foods 23, 453-463.

Huang, S., Chen, X.D., 2013. Significant effect of $\mathrm{Ca}^{2+}$ on improving the heat resistance of lactic acid bacteria. FEMS (Fed. Eur. Microbiol. Soc.) Microbiol. Lett. 344 (1), 31-38.

Huang, S., Gaucher, F., Cauty, C., Jardin, J., Le Loir, Y., Jeantet, R., Chen, X.D., Jan, G., 2018. Growth in hyper-concentrated sweet whey triggers multi stress tolerance and spray drying survival in Lactobacillus casei BL23: from the molecular basis to new perspectives for sustainable probiotic production. Front. Microbiol. 9. Article No. 2548 .

Huang, S., Méjean, S., Rabah, H., Dolivet, A., Le Loir, Y., Chen, X.D., Jan, G., Jeantet, R. Schuck, P., 2017. Double use of concentrated sweet whey for growth and spray drying of probiotics: towards maximal viability in pilot scale spray dryer. J. Food Eng. 196, 11-17.

Huang, S., Rabah, H., Jardin, J., Briard-Bion, V., Parayre, S., Maillard, M.B., Le Loir, Y., Chen, X.D., Schuck, P., Jeantet, R., Jan, G., 2016b. Hyperconcentrated sweet whey, a new culture medium that enhances Propionibacterium freudenreichii stress tolerance. Appl. Environ. Microbiol. 82 (15), 4641-4651.

Huang, S., Yang, Y., Fu, N., Qin, Q., Zhang, L., Chen, X.D., 2014. Calcium-aggregated milk: a potential new option for improving the viability of lactic acid bacteria under heat stress. Food Bioprocess Technol. 7 (11), 3147-3155.

Hudault, S., Lievin, V., BernetCamard, M.F., Servin, A.L., 1997. Antagonistic activity exerted in vitro and in vivo by Lactobacillus casei (strain GG) against Salmonella typhimurium C5 infection. Appl. Environ. Microbiol. 63 (2), 513-518.

Hussain, M.A., Nezhad, M.H., Sheng, Y., Amoafo, O., 2013. Proteomics and the stressful life of lactobacilli. FEMS (Fed. Eur. Microbiol. Soc.) Microbiol. Lett. 349 (1), 1-8.

Karmas, R., Buera, M.P., Karel, M., 1992. Effect of glass-transition on rates of nonenzymatic browning in food systems. J. Agric. Food Chem. 40 (5), 873-879.

Kets, E.P.W., Teunissen, P.J.M., DeBont, J.A.M., 1996. Effect of compatible solutes on survival of lactic acid bacteria subjected to drying. Appl. Environ. Microbiol. 62 (1), 259-261.

Kieferle, I., Hiller, K., Kulozik, U., Germann, N., 2019. Rheological properties of fresh and reconstituted milk protein concentrates under standard and processing conditions. J. Colloid Interface Sci. 537, 458-464.

Kwok, L.Y., Wang, L., Zhang, J., Guo, Z., Zhang, H., 2014. A pilot study on the effect of Lactobacillus casei Zhang on intestinal microbiota parameters in Chinese subjects of different age. Benef. Microbes 5 (3), 295-304.
Lew, L.-C., Hor, Y.-Y., Yusoff, N.A.A., Choi, S.-B., Yusoff, M.S.B., Roslan, N.S., Ahmad, A., Mohammad, J.A.M., Abdullah, M.F.I.L., Zakaria, N., Wahid, N., Sun, Z., Kwok, L.-Y., Zhang, H., Liong, M.-T., 2018. Probiotic Lactobacillus plantarum P8 alleviated stress and anxiety while enhancing memory and cognition in stressed adults: a randomised, double-blind, placebo-controlled study. Clin. Nutr. 38 (5), 2053-2064.

Linders, L.J.M., Meerdink, G., VantRiet, K., 1997. Effect of growth parameters on the residual activity of Lactobacillus plantarum after drying. J. Appl. Microbiol. 82 (6), 683-688.

Liu, B., Fu, N., Woo, M.W., Chen, X.D., 2018. Heat stability of Lactobacillus rhamnosus GG and its cellular membrane during droplet drying and heat treatment. Food Res. Int. 112, 56-65.

Manas, P., Pagan, R., Sala, F.J., Condon, S., 2001. Low molecular weight milk whey components protect Salmonella senftenberg $775 \mathrm{~W}$ against heat by a mechanism involving divalent cations. J. Appl. Microbiol. 91 (5), 871-877.

Mattila-Sandholm, T., Myllärinen, P., Crittenden, R., Mogensen, G., Fondén, R., Saarela, M., 2002. Technological challenges for future probiotic foods. Int. Dairy J. 12 (2), 173-182.

Mille, Y., Obert, J.P., Beney, L., Gervais, P., 2004. New drying process for lactic bacteria based on their dehydration behavior in liquid medium. Biotechnol. Bioeng. 88 (1), 71-76.

Prasad, J., McJarrow, P., Gopal, P., 2003. Heat and osmotic stress responses of probiotic Lactobacillus rhamnosus HN001 (DR20) in relation to viability after drying. Appl. Environ. Microbiol. 69 (2), 917-925.

Rajam, R., Karthik, P., Parthasarathi, S., Joseph, G.S., Anandharamakrishnan, C., 2012. Effect of whey protein-alginate wall systems on survival of microencapsulated Lactobacillus plantarum in simulated gastrointestinal conditions. J. Func. Foods 4 (4), 891-898.

Rogers, S., Wu, W.D., Lin, S.X.Q., Chen, X.D., 2012. Particle shrinkage and morphology of milk powder made with a monodisperse spray dryer. Biochem. Eng. J. 62, 92-100.

Savijoki, K., Suokko, A., Palva, A., Valmu, L., Kalkkinen, N., Varmanen, P., 2005. Effect of heat-shock and bile salts on protein synthesis of Bifidobacterium longum revealed by S-35 methionine labelling and two-dimensional gel electrophoresis. FEMS (Fed. Eur. Microbiol. Soc.) Microbiol. Lett. 248 (2), 207-215.

Saxelin, M., 1997. Lactobacillus GG - a human probiotic strain with thorough clinical documentation. Food Rev. Int. 13 (2), 293-313.

Saxelin, M., Grenov, B., Svensson, U., Fonden, R., Reniero, R., Mattila-Sandholm, T., 1999. The technology of probiotics. Trends Food Sci. Technol. 10 (12), 387-392.

Schutyser, M.A.I., Perdana, J., Boom, R.M., 2012. Single droplet drying for optimal spray drying of enzymes and probiotics. Trends Food Sci. Technol. 27, 73-82.

Silva, F.V.M., Gibbs, P.A., 2010. Non-proteolytic Clostridium botulinum spores in low-acid cold-distributed foods and design of pasteurization processes. Trends Food Sci. Technol. 21 (2), 95-105.

Silva, J., Carvalho, A.S., Pereira, H., Teixeira, P., Gibbs, P.A., 2004. Induction of stress tolerance in Lactobacillus delbrueckii ssp bulgaricus by the addition of sucrose to the growth medium. J. Dairy Res. 71 (1), 121-125.

Somero, G.N., 1995. Proteins and temperature. Annu. Rev. Physiol. 57, 43-68.

Su, Y., Zheng, X., Zhao, Q., Fu, N., Xiong, H., Wu, W.D., Chen, X.D., 2019. Spray drying of Lactobacillus rhamnosus GG with calcium-containing protectant for enhanced viability. Powder Technol. 358, 87-94.

Sun, W.Q., Leopold, A.C., Crowe, L.M., Crowe, J.H., 1996. Stability of dry liposomes in sugar glasses. Biophys. J. 70 (4), 1769-1776.

Sunny-Roberts, E.O., Knorr, D., 2009. The protective effect of monosodium glutamate on survival of Lactobacillus rhamnosus GG and Lactobacillus rhamnosus E-97800 (E800) strains during spray-drying and storage in trehalose-containing powders. Int. Dairy J. 19 (4), 209-214.

Teixeira, P., Castro, H., MohacsiFarkas, C., Kirby, R., 1997. Identification of sites of injury in Lactobacillus bulgaricus during heat stress. J. Appl. Microbiol. 83 (2), 219-226.

Upreti, P., Buhlmann, P., Metzger, L.E., 2006. Influence of calcium and phosphorus, lactose, and salt-to-moisture ratio on cheddar cheese quality: $\mathrm{pH}$ buffering properties of cheese. J. Dairy Sci. 89 (3), 938-950.

Wang, J., Huang, S., Fu, N., Jeantet, R., Chen, X.D., 2016. Thermal aggregation of calcium-fortified skim milk enhances probiotic protection during convective droplet drying. J. Agric. Food Chem. 64 (30), 6003-6010.

Wang, Y., Hao, F., Lu, W., Suo, X., Bellenger, E., Fu, N., Jeantet, R., Chen, X.D., 2020. Enhanced thermal stability of lactic acid bacteria during spray drying by intracellular accumulation of calcium. J. Food Eng. 279, 109975.

Watterlot, L., Rochat, T., Sokol, H., Cherbuy, C., Bouloufa, I., Lefevre, F., Gratadoux, J.J., Honvo-Hueto, E., Chilmonczyk, S., Blugeon, S., Corthier, G., Langella, P., BermudezHumaran, L.G., 2010. Intragastric administration of a superoxide dismutaseproducing recombinant Lactobacillus casei BL23 strain attenuates DSS colitis in mice. Int. J. Food Microbiol. 144 (1), 35-41.

Williams, A.G., Withers, S.E., Banks, J.M., 2000. Energy sources of non-starter lactic acid bacteria isolated from Cheddar cheese. Int. Dairy J. 10 (1-2), 17-23.

Wu, R., Wang, W., Yu, D., Zhang, W., Li, Y., Sun, Z., Wu, J., Meng, H., Zhang, H., 2009. Proteomics analysis of Lactobacillus casei Zhang, a new probiotic bacterium isolated from traditional home-made Koumiss in Inner Mongolia of China. Mol. Cell. Proteomics 8 (10), 2321-2338. 
Zhang, Y., Du, R.T., Wang, L.F., Zhang, H.P., 2010. The antioxidative effects of probiotic Lactobacillus casei Zhang on the hyperlipidemic rats. Eur. Food Res. Technol. 231 (1), 151-158.

Zhao, Y.P., Liu, S., Feng, Y.Q., Bilal, M., 2019. Development and optimization of attapulgite clay based microencapsulation for lactic acid bacteria by Response Surface Methodology. Int. J. Food Eng. 15 (8). Article No. 20190085.
Zheng, X., Fu, N., Duan, M., Woo, M.W., Selomulya, C., Chen, X.D., 2015. The mechanisms of the protective effects of reconstituted skim milk during convective droplet drying of lactic acid bacteria. Food Res. Int. 76, 478-488. 